\title{
CAUSING DEATH AND ALLOWING TO DIE
}

By David J. Atkinson

\begin{abstract}
'Medical ethics are not separate from but part of other ethics'. Such was the theme of one of Ian Kennedy's Reith Lectures (1980).1 Some medical decisions, he says, are matters of technical skill, while others are moral and ethical. They are decisions about what ought to be done in the light of certain values.
\end{abstract}

I repeat this to offer a justification - as it may be felt that I need to - for my own tentative entry into this area, not as a doctor, but as someone who believes that moral theology is not irrelevant to medical decisions.

This paper will concentrate primarily, but not exclusively, on the very sensitive, and difficult, area of the selective treatment of handicapped new-born babies, brought into the headlines again last year in the trial of Dr Leonard Arthur. There was much understandable annoyance expressed at the time concerning the interference of non-medical people into the debate ${ }^{2}$ indeed it was implied during the trial that 'medical ethics' are somehow an entity on their own. But such decisions as Dr Arthur believed it right to make cannot be made without some view of the nature of man and his destiny, his living and his dying, and without a particular method of reaching decisions and a value system on which to base them. That is, there is a moral dimension to medical decisions which may, by definition, not be within the scope of particular medical technical competence. Indeed, such questions seem to be addressed to all of us as people.

May I be bold enough to 'interfere', therefore, to the extent of seeking to tease out some of the questions left

1. Ian Kennedy, 'Unmasking Medicine' quoted in Listener, 27 November, 1980.

2. Cf. with reference to a similar case the Guardian headline, 12 August, 1981: 'Doctor attacks "interference" in mongol baby case.' 
in my mind by the Judge's summing-up in the case of

Regina $v$. Leonard Arthur, and then sketch out a theological perspective from which a range of moral responses to these questions can be assessed?

\section{Summary of the Dr Leonard Arthur case}

On the 3rd, 4th, and 5th of November, 1981, Mr Justice Farquharson gave his summing-up at Leicester Crown Court. He began by noting the enormous importance of the case and saying that 'it really revolves round the question of what is the duty of a doctor when prescribing treatment for a severely handicapped child suffering from a handicap of an irreversible nature, whose parents do not want that child to survive. ${ }^{3}$

The judge later reminded the court that baby John Pearson was born on Saturday morning 28 June, 1980 at Derby City Hospital. It was a normal birth, but the midwife immediately recognised Down's syndrome. Otherwise the baby was apparently healthy. The mother was distraught on hearing of the child's mongolism, and became more definite than most in saying that she did not want the child. Dr Arthur, the consultant pediatrician, saw the baby at noon, and after discussion with the mother, noted 'Parents do not want the child to survive. Nursing care only.' He then prescribed regular doses of the drug dihydrocodeine, which in his later statement to the police he indicated was used by him as a sedative 'which stops the child seeking sustenance'. ${ }^{4}$

There was some dispute in court, and later in the press, 5 about the meaning of 'nursing care only'; in John Pearson's case it was interpreted to mean that he should be kept 'comfortable, warm and cherished' 6 and fed with water but given no milk. The baby developed bronchopneumonia, and became critically ill by the Sunday evening. He died at $5 \mathrm{a} \cdot \mathrm{m}$. the following Tuesday morning, 69 hours old.

3. Paragraph 1D. My comments are based on the transcript of the Judge's summing-up from the official court reporters, Marten, Meredith and Co. Ltd. The references are to the paragraphs of the typescript of the summing-up.

4. Paragraph 47G. In fact, as the Judge pointed out, dihydrocodeine is a pain-killer (Paragraphs 47E-48A).

5. Cf. letters in British Medical Journal 28 November, 1981.

6. , Paragraph 35B. 
The organisation LIFE gave some evidence to the police, and on 5 February, 1981 Dr Arthur was charged with murder. In the course of the trial (which began on 13 October, 1981), evidence came to light ${ }^{7}$ which indicated that death could have been caused by a congenital heart condition from which the child may have been suffering from birth, and/or bronchopneumonia. The charge of murder was dropped in favour of the charge of attempted murder.

The jury decided that the prosecution had not convinced them that Dr Arthur had attempted to murder John Pearson, and he was acquitted on 5 November, 1981 .

\section{A guess at motivations}

Let us try to guess at some of the motivations involved in the medical decision and attempt to put ourselves to some degree in the position of the child's mother and her doctor.

We should not minimise for one moment the pain of realising that a child one has carried for nine months is handicapped in a severe way. Would there not be an immediate sense of withdrawal, a sense of guilt, perhaps of failure, or even of being 'under judgement'? Does this not reflect our human sense of pain at something abnormal within God's world? Handicap often points us to our own handicap, our own abnormality, our own fragility. When handicap is starkly and visibly focussed in another, there is a tendency to withdraw. Was such a withdrawal part of the mother's experience? Was she also influenced by the view that no unwanted children should be brought into the world? Such a view of 'unwantedness equals disposability' has been deeply ingrained into our attitudes through the increase in the practice and propaganda of abortion. Was she simply realistically acknowledging that she would be unable to cope with the emotional and physical demands of caring for a retarded child? Was she influenced by the current dogma that intelligence makes a person more 'valuable' as a person than lack of intelligence, or that persons should be valued only in terms of their potential usefulness to society? And here was her boy with little likelihood of either intelligence or potential usefulness. If any of this was in her mind, we can understand her statement that she did not want him.

7. Paragraph 43D-H. 
What might be going on in the doctor's mind as he is told that the mother has rejected the child? Again, we can only guess. Would there be a belief that the parents' wishes are paramount and that the doctor's task is to support his patient in her decision, especially at this moment of personal tragedy? Did he believe in the moral autonomy of the parents, and that it is no part of medical practice to impose one's own moral views on one's patients? Did he perhaps wish to acknowledge the point Kennedy made: that doctors have no particular authority as doctors in moral decisions? or did he, from motives of compassion, make his own judgment that the child's death was to its advantage and that of the family? We do not know.

What does emerge from this, however, is the clear fact that $\mathrm{Dr}$ Arthur believed there was no overriding right to life for this child which obliged him to overrule the wishes of the parents.

\section{Issues raised by this case}

There are a number of features of the judge's summing-up and of the statements of defence witnesses quoted by the judge, which raise various issues in medical ethics that have far-reaching implications.

(i) First, a firm distinction was. drawn between causing death and allowing to die. There is, of course, an important distinction in law between acts and omissions, ${ }^{8}$ but the use of this distinction in this case blurred rather than clarified the moral position. The judge rightly said that, however serious a handicap may be in a child, 'no doctor has the right to kill it', but then he made this distinction between 'doing an act, a positive act' and 'allowing a course of events or set of circumstances to ensue'.9 He went on to make much of the idea that what Dr Arthur was engaged in was a 'holding

8. The law attributes responsibility for omissions only where there was a duty to do what was omitted. The English law of murder includes the concept of murder by omission - Infanticide Act $1938 \mathrm{s.1}$ (1) and Homicide Act 1957 s. 2 (1).

9. Paragraph 17D. Cf. 18E - 19B. 
operation' - that is, a provisional decision not to treat nor to feed, but to nurse and sedate, until either the parents changed their minds and would accept the child, or until infection took over, causing death. 'By creating that set of circumstances - argue the defence it is a case of allowing nature to take its course. 10

This distinction between a positive action to cause death and a negative decision to 'allow nature to take its course' was apparently underlined by various eminent defence witnesses. The judge quoted Professor Alexander Campbell, Professor of Child Health at Aberdeen, $11 \mathrm{Dr}$ Dunn, consultant in perinatal medicine in

10. Paragraph 23D.

11. When questioned about a situation when a child is born with Down's syndrome and the parents do not want to keep it, Prof. Campbell said that while it would be ethically unacceptable to take the 'humane' course of giving it a considerable overdose of a drug to terminate its life ('I would consider it murder' Paragraph 63C), in the situation of a baby with Down's born with a severe duodenal atresia who would die without surgery, it may be ethically appropriate simply to allow the child to die without an operation. 'It is allowing nature to take its course' (Paragraph 63F).

'You must remember that these decisions are not taken by doctors in the privacy of the home with the parents, as they once were. They are often taken in a very large hospital with a large intensive care nursery and there are many nurses who bear a lot of the brunt for the actual intense caring for these babies. You have got to think of their morale, you have to think of the team spirit, you have to think of the psychology of the thing. That is where I see a lot of distinction between a positive and a negative act' (Paragraph 64G). 
Bristol, 12 and Sir Douglas Black, President of the Royal College of Physicians. The latter, so the judge reported, commented on Dr Arthur's decision in this way:

I regard this as falling within recognised paediatric policy for a severely damaged child. I distinguish between allowing to die and killing. It is a distinction that is somewhat difficult to defend in logic, but I agree it is good medical practice not to take positive steps to end life. ${ }^{13}$

Again:

I say it is ethical that a child suffering from Down's and with a parental wish that it should not survive, it is ethical [sic] to terminate life, providing other consicerations are taken into account, such as the status and the ability of the parents to cope in a way that the child could otherwise have had a happy life.14

The doctors all stress, and I acknowledge, the extreme delicacy of such decisions, but I believe that to maintain the distinction between causing death and allowing to die

12. Dr Dunn said: 'My own criteria for non-treatment would be the presence of a brain disease or a brain malformation' (Paragraph 66G)... 'Sometimes children are born with such frightful handicaps that it is reasonable, or at any rate we think it is, to accept the parents' decision that in the interests of their own child prolonging life is not in that child's interest. No paediatrician takes life, but we do accept that allowing babies to die is in the babies' interests at times' (Paragraph 67B).

He later spoke of withholding food from uncomplicated Down's babies: 'I know of no paediatrician who withholds treatment in the sense which we are talking who regards what he has done as killing the child; the distinction is between non-salvage and taking a positive act to terminate' (Paragraph 74B).

13. Paragraph 78D.

14. Paragraphs $79 \mathrm{H}-8 \mathrm{OA}$. He added: 'Allowing to die means non-treatment or non-intervention, and letting a child die will arise when the child has a defect which unless cured will cause its death, and it is then left to die' (Paragraph 81E). 
in the circumstances of this case has simply made for confusion rather than clarification. It would have been better to focus on the judge's own initial question: 'What is the duty of a doctor?' in circumstances like these.

\section{(ii) The trend towards a consequentialist ethic}

Once a view of morality related to the will of God has been abandoned in favour of a view of morality which begins with man, a variety of views is possible. A predominant view is a version of utilitarianism which assesses the morality of an action wholly in terms of its consequences. Of course traditional Christian morality is also concerned with the consequences of actions as well as the actions themselves and the intentions behind them, but it asks 'What is my duty?' within a framework of good and bad derived from the will of God, and not only in terms of expected consequences. Consequentialism measures the moral character of an action wholly in terms of its effects, in terms of what is believed to be in a person's or group's interests. Responsibility thus becomes not 'What is my duty in the expression of my allegiance to my God and of love to my neighbour?' but 'What action will have the best outcome?'

In the judge's summing-up in the Arthur case, a tendency to a consequentialist ethic was evident at times, in the stress put on the parents' wishes and on what is 'in the interests of the child'. Now in order to measure what is best, it is assumed that it is possible to weigh the value of a child's life, for example, over against other values (such as the family burden of caring for him, the cost to society, or the child's own likely sense of the burdensomeness of his handicap). . It is, however, extremely hard to see how it is possible to bxing all these values on to a common 'measure'. 15 In any case it is insufficient for a Christian to allow the ends to justify the means: means have an independent moral significance. Furthermore, it is not only that consequentialism is a precarious basis on which to take decisions about other peoples' lives. As the

15. John Finnis calls it, in the strict sense, 'senseless' (Natural Law and Natural Rights, Oxford: Clarendon Press, 1980, 113). 
utilitarian philosopher Jonathan Glover has argued, 16 consequentialism undercuts the distinction between acts and omissions on which this case to a large extent rested. The logic of consequentialism is that there is no difference between allowing to die and killing: in each case the consequence is the same: death.

What was it in the minds of the defence witnesses that allowed them to be comfortable with 'allowing nature to take its course' and yet not comfortable with 'killing'. Was it a Christian memory of the 'sanctity of life' (a concept which Glover rejects) or of the moral rule 'Thou shalt not kill'? ${ }^{17}$ Consequentialism itself cannot supply that rule. Perhaps this illustrates that on some issues such as this medical ethics at present is seeking to hold fast to certain principles enshrined in the Chriștian tradition and yet moving towards abandoning the Christian base from which such principles derive. There would have been a different slant to this case had the question not been 'What is in the interests of this child and its parents?' - a question only answerable in very subjective terms - but rather: 'What do the obligations of neighbour love require?'

(iii) Another issue raised by this case is the matter of the right to decide who may live and who should die. The judge made clear the law of murder:

However serious the case may be, however much the disadvantage of a mongol or, indeed, any other handicapped child, no doctor has the right to kill it. There is no special law in this country that places doctors in a separate category and gives them extra protection over the rest ôf us. ${ }^{18}$

But there is implicit in the accounts of some of the witnesses - and the judge did not dissent - that the right of decision as to whether an irreversibly handicapped baby

16. Causing Death and Saving Lives (Penguin, 1977) 92ff.

17. This rule was quoted by the prosecution and endorsed by the judge as 'the law of the land ... the law of any civilised community' (Paragraph 22A).

18. Paragraph $16 F-G$. 
lives or dies, lies with the parents, or perhaps with the doctor and parents together. ${ }^{19}$. It appears that doctors and parents between them are believed to have a joint right to make a decision that a given child should not live. But there is certainly no such right in law. 'The capacity to determine who shall live does not carry with it the right to determine who shall live. 20

(iv) Finally, it is of importance to notice the criteria on which the decision in this case was apparently based. Doctor and parents decided to sedate the child, offer no food, and 'allow nature to take its course', within the constraints that (a) it was irreversibly and severely, handicapped, and (b) it was rejected by its parents. ${ }^{21}$

This leaves us with two questions: Does an irreversibly handicapped child have any right to live, or at least to try? Is what we ought to do determined by what we desire to do? It is clear, furthermore, that some judgement on the worthwhileness of the child's probable quality of life was substantially part of the judge's assessment of the nature of handicap. He referred at length in most pessimistic tones to the handicap of mongolism and indicated that the likely outcome of life in an institution was most undesirable. ${ }^{2}$ This poses the

19. The judge speaks of 'careful consideration with the parents' (Paragraph 23B, 23G). Dr Dunn was quoted as saying: 'I would decide, though not on my own, whether in any particular case it (i.e. brain disease or brain malformation) was so grave that non-treatment was a possible option. There is never a straightforward decision. One does not try to persuade parents, we advise and try to support them in their tragic and difficult decision' (Paragraph 66H).

20. Cf. James M. Gustafson, 'Mongolism, Parental Desires and the Right to Life', in R. F. Weir (ed.), Ethical Issues in Death and Dying (New York: Columbia University, 1977).

21. Ian Kennedy goes so far as to suggest that in this case the judge has made new law on the crime of murder by his directions to the jury (New Society, 7 January, 1982, 13).

22. Paragraphs 15B-16D; 69F. 
question: Should medical judgements regarding appropriate treatment ever be made on the basis that the patient's probable quality of life in the future can be judged not to be worthwhile? Or on the basis of the patient's usefulness or otherwise as a member of society?

\section{A Christian Framework for the Discussion of these Issues}

To begin with, we need a theology of life. Karl Barth summarises his extended chapter. 'Freedom for Life' in Church Dogmatics III/4 in the following words.

As God the Creator calls man to fimself and turns him to his fellow-man, He orders him to honour his own life and that of every other man as a loan, and to secure it against all caprice, in order that it may be used in this service, and in preparation for this service. ${ }^{23}$

The command to live implies, first of all, that our creaturely life is not our own property: it is on loan, and must be held in trust for. God. It is not, therefore, ultimately under our own control. Secondly, as man is not merely physical life, but is 'the soul of his body', he lives as a creature by the life-giving and life-sustaining act of God. Thirdly, individual life is important: God addresses each individually by name, and each must live his own life. We are, Barth observes, commanded to respect. individual life. The birth of Jesus Christ itself reveals the divine command to respect life. ${ }^{24}$ This respect for life means that no individual may choose death or seek to cause his own death or that of another. ${ }^{25}$ To choose death as an end (a goal) is not an option open to the Christian, and therefore in law, in morals and in medical ethics, the boundaries should be clear enough to protect life, respect life, and encourage life, so that no one is encouraged to choose death for himself or for others.

23. K. Barth, Church Dogmatics. III. The Doctrine of Creation. Part Four (ed. G. W. Bromiley and T. F. Torrance) (Edinburgh: T. \& T. Clark, 1961) 324.

24. Ibid. 339.

25. This is not to allocate blame to those who in the darkness of depression attempt to take or succeed in taking their own life. Nor is it to fail to distinguish between choosing death as an end, and foreseeing the likelihood of death as a consequence of seeking another end. Jesus foresaw death when he steadfastly set his face to go to Jerusalem. So did 
We also need a theology of health. The will to live, says Barth, includes the will to be healthy, since health is the strength for human living. Sickness, therefore, is to be seen initially as partial impotence to exercise the psycho-physical functions which are what we mean by 'living' and is to be confronted and resisted. But sickness is not necessarily impotence to be a person. If health is the strength for human existence, even those who are seriously ill can will to be healthy without any optimism or illusions regarding their condition. They are to will to exercise the power that remains to them in spite of every obstacle. ${ }^{26}$ But sickness remains a 'forerunner and messenger of death'. It serves as a reminder, as $\mathrm{Dr}$ Robert Twycross puts it, that 'a doctor practises medicine in the knowledge that eventually all his patients will die. 27 Sickness is 'the inevitable encroachment of the realm of death upon the living space squandered and forfeited by man. ${ }^{28}$ In other words, handicap and disease are painful and visible reminders that we live in a fallen world. On the other hand, sickness concealed (as Barth phrases it) under the form of the messenger of death witnesses to God's creative goodness: it is the forerunner and messenger of eternal life. Christian faith takes the sting out of death, and opens up the hope of resurrection. We need a view of suffering which

Oates when he walked from Scott's tent into the Antarctic blizzard. But they did not 'choose, death'. Rational as suicidal action may seem to a depressed person, to choose death as an end must be judged a wrong act, an omnipotent grasping at a freedom which is not given to us, a grasping which cries out, not for assistance in doing the deed, but for understanding care, medication, therapy, spiritual healing, or whatever will help to lift the depression and make available again to the person involved the freedom to choose life.

26. Barth, Dogmatics III.4. 357.

27. Euthanasia, a Physician's Viewpoint (a lecture to the International Conference on Voluntary Euthanasia sponsored by EXIT, September, 1980) 1 .

28. Barth, Dogmatics III.4. 367 (where Barth is summarising the concept of sickness in the psalins, (Job, and the Synoptic Gospels). 
acknowledges both its pain and its goal. Some are called on to suffer for Christ and in some way can thereby 'share in the sufferings of Christ'. But suffering is never a goal to be sought for its own sake. Jesus, when faced with suffering in others, expressed that mixture of indignation and loving action captured by the word 'compassion', and sought to bring relief and release. He never indicated that a disability was a disqualification for his care; never to a leper or to a paralysed man did he say 'It would have been better for that man if he had not been born'. As Archbishop Coggan wrote in Convictions, 'Jesus, when faced with physical and mental sickness, almost invariably shows himself a fighter. 29 But Christ's own sufferings point us to the redemptive possibilities of suffering: there can be a pain which heals. Human suffering is not an absolute for it may be part of the labour pains of the new creation. ${ }^{30}$ Christ can meet us at the point of pain, and make our suffering an occasion for his strengthening grace. We must, then, seek to alleviate suffering and its causes but must never assume that absence of suffering is life's most important goal.

How does all this translate into the terms of medical responsibility? Although man should will to live and will to be healthy, he must also take account of the facts of sickness, disability and death. This side of the Fall and this side of Heaven, the ambiguity of man's nature is such that handicap, disease and pain are part of the limitations to be acknowledged in living our lives and in aiding others to live theirs. Though we should confront and resist disease and disability, we are not to hold on to life and health as absolutes, to be protected for as long as possible at whatever cost. Medical responsibility would thus seem to involve both the encouragement, protection and preservation of life, and the relief of suffering both for the patient and for others involved. In the situation where these two goals conflict, it will be part of the art of medicine to assess the points at which the lines are to be drawn. The rest of this paper will explore the guidelines that might help in making such decisions.

29. F. D. Coggan, Convictions (Hodder, 1975) 274.

30. Cf. Rom 8. 22 . 


\section{Pain-relieving Medication}

One important question to be raised at this stage is whether the use of medication which may shorten life as well as relieve pain, should be thought of as 'causing death'. One of the main planks on which the EXIT society builds its case in its campaign for the legalising of voluntary euthanasia, is that adequate relief of pain is a right and compassionate course of action. With this I agree. But it is simply confusing the debate to equate this with the deliberate termination of life. Such relief of pain is neither active nor passive, neither direct nor indirect euthanasia (in the sense which that term has come to have): ${ }^{31}$ it is part of responsible medical care and always has been. ${ }^{32}$

From a consequentialist ethical perspective, of course, there may be little difference between administering pain-killers which hasten death, on the one hand, and actively killing, on the other. However, we must underline the importance of intention as part of the very

31. The root meaning of the word is 'dying well', but 'euthanasia' has come to have the much narrower meaning of the deliberate termination of the life of someone who is suffering, apparently irremediably, in the belief that this person would be better off dead. 'Voluntary' euthanasia refers to such termination of life with the consent of the person killed.

32. Pope Paul VI gave this ruling (quoted in Robert Twycross' paper, and elsewhere): 'The duty of the physician consists more in striving to relieve pain than in prolonging as long as possible with every available means a life that is no longer fully human and that is naturally coming to its conclusion.'

The recent Vatican Declaration on Euthanasia (1980) underlines the same principle. It acknowledges that suffering can so affect human psychology as to exceed its biological usefulness. It then reminds us that suffering, especially during the last moments of life, can be related to Christ's saving passion, and has a special place in God's saving plan. Some Christians may thus prefer to moderate their use of painkillers, in order to accept voluntarily at least part of their sufferings. Nevertheless, it would be imprudent to impose a heroic way of acting as a general rule. The Declaration then refers to Pius XII's address 
meaning of moral choice. Every doctor surely knows whether he is intending to relieve pain or to give a fatal dose. Proper relief of pain is part of responsible medical care; it should not be confused with euthanasia. To quote Robert Twycross again, the aim of using pain-killing drugs such as diamorphine in the treatment of terminal cancer is 'to keep the patient both free of pain and fully alert'. To seek to achieve that balance is part of the art of medicine.

With regard to the case we have been considering, however, neither the causing of death directly, nor the administration of pain-relieving drugs for the sake of easing pain, was the point at issue. It may have been that the dosage of dihydrocodeine contributed to John Pearson's death, but that was not why it was administered. It was administered to stop the child seeking sustenance in the hope that it would die. We must, then, move on to this central question: Is there a morally significant difference between causing death and allowing to die?

\section{6. 'Allowing to die'}

From a consequentialist point of view, there is no morally significant difference between allowing to die and causing death. However I would wish to affirm that sometimes there is, sometimes there is not. This issue is part of the more general moral distinction between acts and omissions, and as Jonathan Glover rightly illustrates, ${ }^{3}{ }^{3}$ there are different types of omission. Sometimes when I do not do something, it would be entirely unreasonable to blame me for not doing it. At other times an omission would be morally blameworthy. What would count as a morally significant omission? It would be omitting to do

(February, 1957) in which he answered the question: 'Is the suppression of pain and consciousness by the use of narcotics ... permitted by religion and morality to the doctor and the patient (even at the approach of death and if one furesees that the use of narcotics will shorten life)?' The Pope said: 'If no other means exist, and if, in the given circumstances, this does not prevent the carrying out of other religious and moral duties, Yes.' In this case, continues the Declaration, death is in no way intended or sought, even if the risk of it is reasonably taken; the intention is simply to relieve pain effectively. 33. J. Glover, Death 95. 
something, which in the circumstances concerned, one was morally obliged to do. R. C. Mortimer puts it this way: 'To be held responsible for the consequences of my failure to act, it must be shown (i) that I foresaw or should have foreseen the consequences; (ii) that I could have acted; and (iii) that I had a duty to act. ${ }^{34}$ In other words, I must have the ability, the opportunity, and be under an obligation to act, if my failure to act is morally significant.

Is 'allowing to die' a morally blameworthy omission? quite clearly sometimes it is, and sometimes it is not. Sometimes omitting to act derives from lack of ability to act: patients are 'allowed to die' because the resources are not available to help them to live. Again, sometimes patients are 'allowed to die' when there is no moral obligation on a doctor to seek to keep them alive any longer. We will take both of these cases further shortly, but in neither case is the omission morally equivalent to intentionally causing death. But sometimes the doctor does have the resources and the opportunity. If it is judged that he is also under a moral obligation to act in the circumstances of his case and he then fails to do so, such omission of treatment - if it results in the death of the patient who would otherwise live - is, I judge, morally equivalent to killing. It may be precisely not allowing nature to take its course. It may not be 'allowing to die': it may rather be 'not allowing to live'. In the case of a handicapped baby, otherwise healthy, who is unable to give his consent, I would judge this to be involuntary euthanasia.

Another way of focussing the distinction between an act and an omission in the sort of case we have been considering is to distinguish between intention and mere foresight. An omission of treatment in the care of the dying child would not be morally blameworthy if the doctor merely expected that the child would die, without any accompanying intention that he should (though with the intention that his dying should be as comfortable as possible). An omission of treatment combined with an intention that the child should die would be a morally blameworthy omission.

7. 'Allowing to die' because of insufficient medical resources Many of the decisions which affect the treatment available to

34. R. C. Mortimer, The Elements of Moral Theology (Black, 1947) 51 . 
patients are not made by doctor and patient, but by those who have the difficult task of allocating health care resources. This was not a direct issue in the Arthur case, though we may surmise that the decisions reached by parents anc doctor may have been affected by the disagreeable prospect of institutional care for the child (described in depressing terms by the judge). ${ }^{35}$ Would decisions be different if it were known that more resources were available for intensive and extensive care for the handicapped, and more adequate provision for educational and social support? Funds, however, are not unlimited. Who should benefit when it is clear that not all can? An adverse decision (for example in the allocation of renal dialysis machines) will mean that some are 'allowed to die'.

The quest:ion is not necessarily one in which direct responsibility rests on the doctor, nor indeed on the regional health authorities. Even if we wished to give treatment, there are some situations in which resources are not available. At one level this is a global question. It is part of the problem of the distribution of earth's resources to which the Brandt Report addressed itself. How many hundreds of thousands of people are being 'allowed to die' through the greed and neglect of others? At the national level, this is a question of budget priorities. Decisions have to be made on the allocation of funds to reequip the Navy, to develop ever more sophisticated weapons of mass destruction, to provide health care. How, a Christian must ask, can we work towards justice in the restructuring of social priorities? ${ }^{36}$

35. Cf. the judge's summing-up (Paragraph $16 \mathrm{C}-\mathrm{E}$ ).

36. On a related issue of health care resources for the dying, the Journal of Medical Ethics (1975, p. 1) made this editorial comment: 'The debate about euthanasia is most fruitfully transposed into a discussion about priorities in the training of medical personnel and the provision of resources in the place where people die. Why is it that expertise in relieving pain and in maintaining a human environment for dying is so rare in modern medicine? If a good death is sought after it will be better ensured, not by removing sanctions against "mercy killing", but by revising the calculations of health budgets which leave the act of dying out of the equation.' 
Granted, then, that funds for health care are inevitably limited, how are available funds to be distributed? If we were to allocate on the basis of 'equal life', (viz. that available resources should be equally shared) there would be discrimination in favour of the healthy and against those who are ill. If we were to allocate on the basis of life expectancy (e.g. that someone with twice the life expectancy of another should have twice the allocation), that also would discriminate unjustly. If we are not willing to say that 'all should die when not all can be saved' (i.e. that if there is a choice between two persons, neither should benefit if both can not), there seem to be two courses open.

First, we could opt for a policy of random selection, such as Paul Ramsey favours. He bases this on concern for the sanctity of life which requires allocation not on pragmatic criteria or social worth, but on the equal right of every human being to live. To base the decision on any criteria offends against this right, whereas the ultimate equality of all men in the sight of God requires, says Ramsey, that we 'imitate God's care alike for the good and the bad, the profitable and the unprofitable, the deserving and the undeserving, and seek to serve those who are only needy no less than those who are needed. In allocating sparse medical resources among equally needy persons, an extension of God's indiscriminate care into human affairs requires random selection and forbids godlike judgements that one man is worth more than another. 37

Alternatively, we could try to use pragmatic criteria, as Helmut Thielicke suggests. But he rightly observes that such decisions should be taken out of the hands of any one person. There must also be acknowledgment of the real pain of the decision itself. 'Whoever understands man purely in terms of the functions he can perform will never suffer when he is compelled to judge in the realm of the incommensurable... But whoever suffers under the unbelievable constraint of having to judge, whoever experiences in the impossibility of his task the feeling of "metaphysical guilt" remains sound and healthy where it really counts... Whoever knows that in this sphere he cannot come through without taking guilt upon himself, whoever knows also the comfort of forgiveness, will find his ethos sound and healthy,

37. Paul Ramsey, The Patient as Person (Yale, 1970) 259. 
immune from the temptation to press the humanum into a scale of values, and thereby pervert it. ${ }^{38}$

Perhaps some combination of the concern which underlies Ramsey's (perhaps over-strict) position and Thielicke's use of criteria is possible. ${ }^{39}$ We could have a policy of exclusions, excluding those who are unlikely to benefit from treatment or those for whom treatment would impose excessive burdens of one sort of another. We should weigh other factors that are relevant to the continuance of a person's life and might be morally significant in assessing cost and burden - factors such as special family circumstances (as in the case of a mother with small children). For the rest, we could operate a policy of random choice.

Whichever way decisions are made, we are forced to face the need to establish social priorities in this area. ${ }^{40}$ To be "pro-life" commits us not only to inquiring into the agonising choices facing doctors and parents of handicapped children. It commits us even more to facing the need for adequate health budgets to provide medical care, social support, and educational opportunities for handicapped people. Medical decisions such as those made in the Arthur case cannot be separated from the question of social priorities.

38. H. Thielicke, The Doctor as Judge of Who Shall Live and who Shall Die (Philadelphia: Fortress, 1970) 28.

39. Cf. Linacre Centre Booklet, Prolongation of Life. (iii) Ordinary and Extraordinary Means of Prolonging Life (1979) 18.

40. Cf. C. Curran, 'Medical Ethics' in Politics, Medicine and Christian Ethics (Philadelphia: Fortress, 1973) 144. 'I realise the impossibility of any exact hierarchical ordering of all these needs, but men can and should come up with a rather rough idea of the areas that should be emphasised. Many times one can be more certain of negative judgements - areas that should not receive as much emphasis as they do now ... We can and must do more than just say that the problem is almost impervious to human reason.' 


\section{8. 'Allowing to die' and 'not artificially prolonging dying'}

There is a sense in which 'allowing to die' can mean 'not artificially prolonging the dying process of a dying patient'. The moral question here is whether it is right always to seek to prolong such a patient's life at all costs.

Bonhoeffer is surely right in his insistence that natural life $^{41}$ is at one and the same time a means to an end and an end in itself. To absolutise life only as a means to an end - whether that be the common good, or the Vision of God leads to what Bonhoeffer calls the 'mechanisation' of life, in which the individual's bodily life is important only in terms of his value for the group, or as a physical means to a spiritual end. Life then loses significance, and is ultimately sacrificed in the process. On the other hand, to absolutise life as an end in itself (which Bonhoeffer calls 'vitalism') separates life from the ultimate goals which give it meaning and significance, and so again 'plunges it into the void of meaninglessness'.42 We must affirm the tension and paradox of life as both a means and an end, and seek to avoid the extremes which make an absolute of one or the other.

Sometimes medical decisions are based on the belief that life is an absolute before which all else must be sacrificed. The irony is that, because of the availability of increasingly sophisticated technology, such 'vitalism' leads to the possibility of extending life's length at the expense of life itself, and so effectively 'mechanises' the processes of dying. Thielicke comments (in a slightly different context): 'It is shocking to think of the idea that instead of man being the measure of things, the things he has made the structures of technology, progress, indeed the whole cultural apparatus - should come to determine the lines along which man himself is to be structured. ${ }^{43}$ Each

41. 'Natural Life' means for Bonhoeffer, 'that which, after the Fall is directed towards the coming of Christ'. On this section see D. Bonhoeffer, Ethics (London: SCM, 19552) 121 ff.

42. Ibid. 125.

43. H. Thielicke, Doctor 5 . 
step forward in medical technology may bring with it new possibilities for prolonging life. But sometimes technology can be used to prolong what in fact is the terminal stage of a patient's last illness, and in doing so may hinder rather than help their living while dying. Some of the supporters of EXIT are right, in my view, in their concern to avoid such artificial prolonging of dying. But it is confusing to bring this under the heading 'euthanasia'. A point of decision is reached when further treatment may no longer be curative and then medical responsibility shifts from that of sustaining life and making available resources for living, to that of allowing a dying person to die and making their dying as comfortable as possible. ${ }^{44}$ A doctor has no duty to preserve life 'at all costs'. But that does not make it a decision between 'treating' and 'not treating'; rather the question must be 'What is appropriate treatment?'

Is not the doctor's duty to the dying, therefore, to care, and as Ramsey puts it, 'only to care'? In other words, he should avoid inappropriate interventions which in fact only prolong dying. Those who are dying should, with all care, be 'allowed to die.'

\section{Some Guidelines for Decisions}

While it may be relatively straightforward in some circumstances (for example, with advanced cancer in a very elderly person) to be clear as to whether or not a person is dying, and to make a decision to cease further curative treatment and ease their dying, in other situations (such as those involving handicapped infants) the decisions may be much more complex. ${ }^{45}$ What guidelines have been suggested for assessing what appropriate treatment might be? What would the obligations of neighbour-love amount to in these cases?

44. Cf. R. Twycross, Euthanasia.

45. Cf. the paper by R. S. Duff and A. G. M. Campbell, 'Moral and Ethical Dilemmas in the Special Care Nursery' in R. F. Weir (ed.), Ethical Issues. 


\section{(i) 'Indicators of personhood'}

In Humanhood: Essays in Biomedical Ethics Joseph Fletcher affirms that what is critical in biomedical ethics is personal status, not merely human status. He offers a tentative profile of man, a list of fifteen positive and five negative 'indicators' of personhood. These include: minimum intelligence, a degree of self-awareness, capacity for self-control, a sense of the passage of time and of futurity, conscious recall of the past, the capability to relate to others, a capacity of concern for others, communication with others, a responsible control of existence, curiosity, being open to change and creativity in his life, a right balance of rationality and feeling, being idiosyncratic in the sense of having a recognizable individuality, having a functioning cerebral cortex. Negatively, man is 'not non- or anti-artificial' (that is, men are 'characterised by techniques and should welcome technology'); man is not essentially parental, not essentially sexual, is not a bundle of rights, is not a worshipper. ${ }^{4}$ Fletcher recognises the provisional and controversial nature of this series of 'indicators' but none the less believes it important to characterise personhood in this way as a series of capacities.

It is difficult to distinguish this approach from that of the President of the National Secular Society, Ms. Barbara Smoker, who wrote to the Guardian on 11 August, 1981, following the decision of the Appeal Court to require an operation on a Down's syndrome baby girl with a duodenal obstruction, whose parents refused their permission.

'The inhumane decision of two Appeal Court Judges in the case of a new-born mongol baby girl shows lack of understanding of the very basis of human rights. ... What makes us complete human persons is the development of human relationships; what gives us a stake in life is life-experience. A new-born baby, even a perfectly normal one, cannot therefore have a right to life ... (although she adds:) newborn babies in common with all sentient animals, have a natural right to be protected from unnecessary suffering.'

46. J. Fletcher, Humanhood: Essays in Biomedical Ethics (New York: Prometheus, 1979) 7-19. 
On this view, we are being asked to value human personhood in terms of certain qualities which we may or may not possess. The criteria for determining whether to treat patients as persons would therefore depend on their satisfying certain minimal requirements. But is this not a wholly unchristian position? Not only is life, as Barth puts it, an 'alien dignity' conferred by God; the whole doctrine of justification by grace indicates that at no point does personal worth depend on works, abilities or capacities.

\section{(ii) A 'worthwhile' quality of life}

Other writers suggest that there is such a thing as a life not worth living, and measure the 'worthwhileness' of life in terms of such criteria as the degree of hardship and suffering expected for the patient, or the excessive cost to family or society in keeping him alive. Is the future quality of life, it is asked, consistent with self-respect? will the infant grow to be able to earn his own living in competitive employment and be a self-supporting member of society? These, I believe, are the considerations underlying the programme for the selective treatment of spina bifida babies advocated by Professor John Lorber in Sheffield. He offers a group of five adverse criteria based on the view that a child suffering from these will not have a worthwhile life. Such a child is then selected for non-treatment, and is so managed that he dies loften in the first week or two, always before 9 months old)..4 We shall consider this further in a moment, but for the present we might observe that God's care is not based on any criterion of worthwhileness in a person's quality of life. Should our care be based on such a criterion? 'It was not that you were more in number than any other people that the LORD set his love upon you, for you were the fewest of all peoples; but it is because the LORD loves you' (Dt. 7.7).

47. J. Lorber, 'Ethical Problems in the Management of Myelomeningocele and Hydrocephalus', Journal of the Royal College of the Physicians of London 10 (1975) 47-60; 'Early Results of Selective Treatment of Spina Bifida Cystica', British Medical Journal (27 October, 1973) 201-202; and other papers. 


\section{(iii) 'Relational potential'}

One contemporary Roman Catholic theologian, Richard McCormick, while not suggesting any scale on which a person's value or worthwhileness may be judged, nevertheless believes that the question may be: 'Is there a point at which the life that can be saved is not 'meaningful life'? He believes that the sophistication of modern medicine is forcing the question on us: Granted that we can easily save the life, what kind of life are we saving? 'This is a quality of life judgement. And we fear it. And certainly we should. But with increased power goes increased responsibility. Since we have the power, we should face the responsibility. 148 McCormick speaks of life as a 'good', but not an 'absolute good'. Life is to be preserved, he says, but not for its own sake, but precisely as the condition of other values. ${ }^{4 y}$ In the Judaeo-Christian perspective, he argues, the meaning, substance and consummation of life are found in human relationships, and the qualities of justice, respect, concern and compassion and support that surround them. It is neither inhuman nor unchristian, says McCormick, to believe that there comes a point where an individual's condition itself represents the negation of any truly human, that is relational potential. When that point is reached, is not the best treatment no treatment? The task for doctors, McCormick suggests, is to attach relational potential to presumptive biological symptoms. $\$ 0$

Here, then, is a distinction between biological life and relational potential, and the suggestion that some severely handicapped people have already reached their potential under God in their earliest moments. My unease with this position is that it is not clear how anyone could ever make a judgement that a given life had achieved its potential, and that it had therefore ceased to exercise a claim on us as personal life. There are many people in geriatric wards who would not satisfy many criteria for 'relational potential'; are we at liberty on this basis to decide that their claim to

48. R. McCormick, How Brave a New World? (London: SCM, 1981) 344-345.

49. Ibid. 345 .

50. Ibid. 348-350. 
medical care and protection has ceased? And even if we could make such a judgment accurately, would not this be arrogating to ourselves an area of decision which properly belongs within divine providence? And how are we to regard irreversibly comatose individuals? Paul Ramsey comments: 'Persons are not reducible to their potential. Patients are to be loved and cared for no matter who they are, and no matter what their potential for higher values is, and certainly not on account of their responsiveness. Who they are in Christian ethical perspective, is our neighbours. They do not become nearer neighbours because of any capacity they own, nor lesser neighbours because they lack some ability to prevail in their struggle for human fulfilment. 51

\section{(iv) Oräinary and extra-ordinary means}

A further search for guidelines may be illustrated by the distinction between ordinary and extra-ordinary medical means, often made by Roman Catholic writers on these sorts of issues. These terms are not always used in the same way. In medical usage, 'ordinary' has come to refer to normal and tried medical procedures with a good likelihood of benefit, and 'extraordinary' refers to more unusual procedures involving risk, excessive burdensomeness, heavy cost, or uncertain benefit. In Roman Catholic moral theology, however, the term 'ordinary' (as applied to medical treatment) also carries with it the sense of 'obligatory'.

Initially the distinction was used to clarify a competent patient's own decision whether to accept or refuse treatment, but it has been extended to cover 'non-competent' patients in cases such as we have been considering. 52 It is a distinction well expounded in the Linacre Centre booklet of this title. ${ }^{53}$ Commenting on decisions with respect to handicapped newborn babies, the author rejects the

51. Paul Ramsey, Ethics at the Edges of Life (Yale University, 1978) 226-227.

52. In 1957 Pope Pius XII used this distinction in his address to an international congress of anaesthetists. It was also used by Pope John Paul II in the 1980 Vatican Declaration on Euthanasia, which, however, notes that some today prefer to speak of 'proportionate' and 'disproportionate' means.

53. Linacre Centre Booklet, Prolongation of Life. (iii) ordinary and Extraordinary Means of Prolonging Life (1979). 
view that such decisions should be made on the basis of a judgement about the worthwhileness of their probable quality of life. The only appropriate basis for a decision not to treat, he says, is a judgement that the treatment would be too burdensome to the baby, or that the possible benefit would be disproportionately small in relation to expenditure of skill and other resources. In this course, the focus is not on the worthwhileness of the child's quality of life, but on the treatment and its likely benefit or otherwise. The questions to ask are: (i) Is there a reasonable expectation of successful treatment? and (ii) Will that treatment improve the condition of the baby, or will it achieve too little or even perhaps make conditions more intolerable for the child?

We agree that it is right to focus attention on a medical judgement about the benefit that treatment could offer but it is not clear that such a 'medical indications' policy is aided by holding on to the traditional ordinary/extra-ordinary distinction." The way it is often interpreted suggests that a means may be either ordinary or extraordinary depending on the condition or context of the patient. ${ }^{4}$ The concepts are flexible, and what might be considered extraordinary in one situation might be ordinary in another. Here the terms become relativised to the condition of the patient. Are we implicitly moving to a judgement based on the patient's quality of life? That, at least, is the judgement of one commentator on this distinction. 55

54. The Vatican Declaration on Euthanasia, for example, refers to the 'state of the sick person' thus: 'In any case it will be possible to make a correct judgement as to the means by studying the type of treatment to be used, its degree of complexity or risk, its cost and the possibilities of using it, and comparing these elements with the result that can be expected, taking into account the state of the sick person and his or her physical and moral resources.'

55. Helga Kuhse, in Journal of Medical Ethics 5 (1979) 76, quoting B. Steinbock. 
Here we find a confusion between 'quality of life' referring to essential 'medical diagnosis and prognosis' with respect to a particular 'good' of the patient - his health - and 'quality of life' as a general comment on the 'worthwhileness and value' of his life as a whole. Would it not make for clarity to avoid the related 'ordinary/extraordinary' distinction, and base decisions, as the Linacre booklet in fact does, on a 'medical indications policy' of the likelihood of benefit?

Furthermore, the term 'extraordinary' is regularly used by those who wish to withhold treatment with the intention that the patient should die, and that - as we have indicated - is well on the road to involuntary euthanasia. ${ }^{56}$

\section{(v) A 'medical indications policy'}

Following on from (iv), we conclude by referring to the work of Paul Ramsey and his advocacy of a 'medical indications policy'. He regards it as essential to determine what treatment is medically indicated in the case of non-terminal patients, and whether any curative treatment is medically indicated in the case of the dying. This, he says, is an objective medical determination - albeit with margins of disagreement and error. It is not related to some idea in the doctor's mind of 'standard medical care' or to any judgement about the worthwhileness of the patient's quality of life or his potential. It is simply: Can I offer treatment that will improve this patient's condition? If we exclude here certain considerations with regard to the patient's own right to refuse treatment, the answer is: if I can help, I should.

'Letting die' says Ramsey, is a justifiable, even commendable alternative for the dying, for this does not require any comparison of patients or of different conditions of the same patient in order to determine his quality or potential. It requires simply a comparison of treatments to determine whether any are likely to be beneficial. 57

56. Ramsey, Ethics 201 .

57. Ibid. 178. 'Beneficial', that is, in any way 'other than prolonging dying (which is of no benefit to unaware patients, and for the conscious ones only in special circumstances, such as affording them an opportunity to make a will or to have their last reconciliation with God or a family member).' 
For the non-dying also, there can be clinical judgements not to treat, but the decision is based on the belief that the treatment would be of no benefit, not on the view that the patient does not qualify for treatment. There may be a need to explore further what counts as 'benefit', and how to react if burdens outweigh benefits, but the primary point is clear. We need to be alert also to the situations in which 'dying' and 'non-dying' are terms relative to treatment. A person may not be 'dying' if he had earlier been treated. In the situations we are considering here, the distinction is clear.

The debate between Professor Zachary and his former colleague at Sheffield, John Lorber, regarding the management of spina bifida points up these issues. Lorber, we recall, proposed certain criteria for selecting those infants who should be allowed to die, and then managed them to ensure that death occurred before too long by a strict policy of non-treatment and sedation. Zachary also operates criteria for selection, but not selection for death, rather a 'selection based on sound medical and surgical principles and a knowledge of the prospects with and without surgery. 150 The medical question is: Can I help, or only care? In a letter quoted by Ramsey, Zachary suggests that, in Lorber's approach, sedative drugs are given in order that the child will not seek food. He calls this 'slow euthanasia', 'and I think that if people are convinced that it is the right thing to do they should not shrink from calling it by its proper name. 159 I believe this is a right view. The 'benign neglect of defective infants' is a form of involuntary euthanasia; when a policy of non-treatment is entered into with the intention that the child should die, I see no morally significant distinction between allowing to die and causing death.

It seems to me that there is only one way of avoiding the charge of causing death and the related consequence that

58. R. B. Zachary, 'Life with Spina Bifida' British Medical Journal (3 December, 1977) 1460-1461. Cf. also Lancet 2 (1968) 274 .

59. Cf. Ramsey, Ethics $195 \mathrm{ff}$. 
medical care then becomes a function of the inequities that exist at birth, which as Ramsey says 'adds injustice to injury and fate'.60 This is to operate a 'medical indications policy' such as Ramsey and Zachary outline. It requires more careful consideration than we can give here of a patient's own wishes and of the question of the allocation of health care resources. But such a policy should not be urged without also urging a more adequate response at community level to underst.anding and sharing the pain of a burdened family, and seeking to provide facilities to aid the physical and later psychological needs of such handicapped children. The Helen House hospice currently being built in oxford is one shining example of the sort of way such care might and must be offered. Such considerations are an essential part of deciding how to respond in the face of the appalling tragedy of severe handicap at birth, while at the same time affirming that the defective infant is my neighbour, with a claim on me tọ neighbour love. He, despite all deformity, is also but a little lower than the angels. He surely comes within the category of those of whom our Lord spoke: the hungry who need food, the thirsty who need drink, the stranger who needs welcome, the naked who needs shelter and care. 'Truly I say to you, as you did it to one of the least of these my brethren, you did it to me ... As you did it not to one of the least of these, you did it not to me. ${ }^{61}$

60. Ramsey, Ethics 202.

61. Mt. $25: 40,45$. 